\title{
Comparing peasants' perceptions of precipitation change with precipitation records in the tropical Callejón de Huaylas, Peru
}

\author{
Wolfgang Gurgiser ${ }^{1}$, Irmgard Juen ${ }^{1}$, Katrin Singer ${ }^{2}$, Martina Neuburger ${ }^{2}$, Simone Schauwecker $^{3,4}$, \\ Marlis Hofer ${ }^{1}$, and Georg Kaser ${ }^{1}$ \\ ${ }^{1}$ Institute of Atmospheric and Cryospheric Sciences, University of Innsbruck, Innsbruck, Austria \\ ${ }^{2}$ Institute of Geography, University of Hamburg, Hamburg, Germany \\ ${ }^{3}$ Institute of Geography, University of Zurich, Zurich, Switzerland \\ ${ }^{4}$ Meteodat GmbH, Zurich, Switzerland \\ Correspondence to: W. Gurgiser (wolfgang.gurgiser@uibk.ac.at)
}

Received: 19 August 2015 - Published in Earth Syst. Dynam. Discuss.: 9 October 2015

Revised: 25 April 2016 - Accepted: 6 May 2016 - Published: 26 May 2016

\begin{abstract}
Pronounced hygric seasonality determines the regional climate and, thus, the characteristics of rainfed agriculture in the Peruvian Callejón de Huaylas (Cordillera Blanca). Peasants in the Cuenca Auqui on the eastern slopes above the city of Huaraz attribute recently experienced challenges in agricultural production mainly to perceived changes in precipitation patterns. Statistical analyses of daily precipitation records at nearby Recuay (1964 to 2013) and Huaraz (1996 to 2013) stations do not corroborate the perceived changes. Either insufficient temporal resolution of available precipitation records or other environmental and sociopolitical factors impacting traditional farming methods may be the reason for the lack of concordance between the two information sources investigated in this study.
\end{abstract}

\section{Introduction - considering different perspectives on a complex problem}

Scientific evidence of climate warming and of projected resulting impacts can provide the basis for a responsible and efficient adaptation strategy if implemented in a timely and careful fashion, but can also be misused to legitimize particular interests (Arnall et al., 2014; Dietz, 2011; Neuburger, 2008). While the physical aspects of climate change are, though complex, of relatively straightforward nature, societal processes in reaction to them are contingent upon and characterized by the different interests, positions and vulnerabilities of affected groups (Postigo et al., 2008; Sietz, 2014; Zimmerer, 1993).

A region of specific interest is the Callejón de Huaylas (the valley drained by the Río Santa) in Peru, where water availability is determined by particular climate and topographical settings (e.g., Kaser et al., 2003). While the tropical atmosphere is thermally homogeneous, the region is charac- terized by single-peaked hygric seasonality. Precipitation increases from August towards the October to April core wet season and is close to nil during June and July (e.g., Bury et al., 2010; Kaser and Osmaston, 2002; Mark et al., 2010; Schauwecker et al., 2014). Dry season runoff, and thus water supply, is comprised of up to two thirds glacial melt water from the Cordillera Blanca (e.g., Baraer et al., 2012; Kaser et al., 2010; Mark and Seltzer, 2003, 2005). They smooth the seasonal runoff to a degree that varies with the proportion of sub-catchments that are covered by glaciers (e.g., Kaser et al., 2003; Mark and Seltzer, 2003). While the highest glacier cover of up to $41 \%$ is found in the northern Cordillera Blanca valleys, rivers draining the western Cordillera Negra are lacking in glacier contribution (e.g., Kaser et al., 2003).

Glacier contribution definitely has a considerable effect on the runoff of the Río Santa during the dry season (Bury et al., 2013; Carey et al., 2014) and even more so on the tributaries draining the Cordillera Blanca. Both ancient and modern channel systems have witnessed the sophisticated use of 
river water for agriculture and other needs (Bury et al., 2013; Gelles, 2001). Many studies were dedicated to the impact of glaciers on runoff and water availability in the region (Baraer et al., 2012; Carey et al., 2014; Mark et al., 2010). The increasing knowledge of human-caused climate warming and resulting impacts has attracted much attention in the region up to now (Baraer et al., 2012; Bury et al., 2013; Carey, 2010; Carey et al., 2014; Chevallier et al., 2011; Juen et al., 2007; Mark et al., 2010; Vuille et al., 2008) and, among other interests, our interdisciplinary research team also focuses on this issue.

Yet, by gradually deciphering natural components of water availability, societal practices of water use, and emerging trends of water conflicts, we have identified important nonglacial aspects of the question of water supply in our study region. Even on the slopes of the heavily glaciated Cordillera Blanca many small-scale farmers have no access to nearby glacier-fed river runoff due to unequal land and water distribution systems.

Accounts from local peasants suggest that changes in precipitation patterns, e.g., during the onset of the wetter season (August-September), the traditional period for ground preparation and first seeding, have caused detrimental effects on the crops' growth and, thus, on overall agricultural production. However, human perception can often fail to accurately determine the drivers of concern (e.g., precipitation, solar radiation, temperature, deforestation, changes in seed types etc.) for the experienced impacts (changing soil moisture, problems with seedlings and harvests). A full range analysis of crop yield and precipitation data, of forest degradation, soil erosion, changing seeds, cultivating methods, development and/or liberalization of agricultural markets, political programs and dominant discourses etc. would lead to a most comprehensive answer to whether and why crop yields may have changed and how counter measures could be applied. Yet sustainability farming is rarely accompanied by systematic data collection and change monitoring, hindering a comprehensive analysis of drivers of alterations in crop growing. General statistics on agricultural production changes for the entire Department of Ancash do not allow for the derivation of local information and understanding the complexities of changes (Bury et al., 2013).

Also, precipitation data in the Callejón de Huaylas have been recorded more from the perspective of hydropower use than of agriculture, and thus long-term measurements with high temporal resolution (at least daily values) as required for analyzing potential impacts on crop yields are rare. Nevertheless, for this study we were able to assemble time series of daily precipitation totals for two sites in the Southern Cordillera Blanca, for the periods 1964 to 2013 and 1996 to 2013 respectively. These data allow us to examine one potentially powerful (and the most blamed) driver of the experienced changes in rain-fed agriculture.

In this study we examine the issue by (i) characterizing agricultural practices of Andean peasant families along the
Río Auqui (crop types used, seasonal cycle of sowing, growing and harvesting) and presenting and evaluating the peasants accounts of changes, (ii) analyzing available information on local precipitation, and (iii) touching on potential effects on small-scale farming as far as possible from available data. Aspects of climate change impacts not investigated in this study and potential other disturbances of agricultural performance will be briefly referred to in the discussion section.

The outcome of this study may shed light on other peasant communities in the region whose economy is based on rain-fed agriculture and, more generally, on mountain regions with similarly vulnerable communities and with similarly poor availability of information. It also takes account of potential complications caused by the different approaches of scientific groups in an interdisciplinary setting and by bringing together epistemologies represented by Western scientific knowledge with peasants' local knowledge (e.g., Boelens, 2014; Escobar, 2008; Klein et al., 2014; Lennox and Gowdy, 2014). We emphasize that this study only concentrates on one variable (precipitation) out of a series of potentially interrelated variables explaining perceived changes. It will, therefore, rather point out open questions then provide conclusive answers to the complex problem. In fact we consider the outcome of our methodical experiments at the interface of the, by their nature, explicitly different knowledge systems as a major result. We therefore provide the details of the approaches taken from both sides for providing insight to readers from different scientific disciplines.

\section{Study site}

Our study site (here called Cuenca Auqui) stretches from the city of Huaraz along the slopes south of the Río Auqui up to the highest settlements close to Río Shallap and includes five main villages with about 1500 inhabitants in total: Los Pinos, Ichoca, Collyur, Paquishka and Jancu (Fig. 1). The narrow bottom of the valley is well-defined by steep slopes reaching altitudes up to $4500 \mathrm{~m}$ a.s.l. that become gentler towards the crests. Aside from some houses at the valley flanks, all settlements are located close to the road at an altitude of $3200 \mathrm{~m}$ a.s.l. (Los Pinos) to $3800 \mathrm{~m}$ a.s.l. (Jancu). The cultivation area in the Cuenca Auqui is naturally concentrated towards the valley bottom but also extends to the adjacent slopes. Irrigation is currently only available for relatively small areas close to the river (Fig. 1). The irrigation channel along the upper slopes has never been in operation yet. Since 2014 it is under reconstruction to improve the urban water supply. From a hydrological viewpoint the Cuenca Auqui stretches from the Río Santa into the heavily glaciated Cordillera Blanca, which together with the ice-free Cordillera Negra in the West, defines the Callejón de Huaylas.

With the implementation of the agrarian reform in 1969, four former haciendas (colonial large-scale farms) at the 


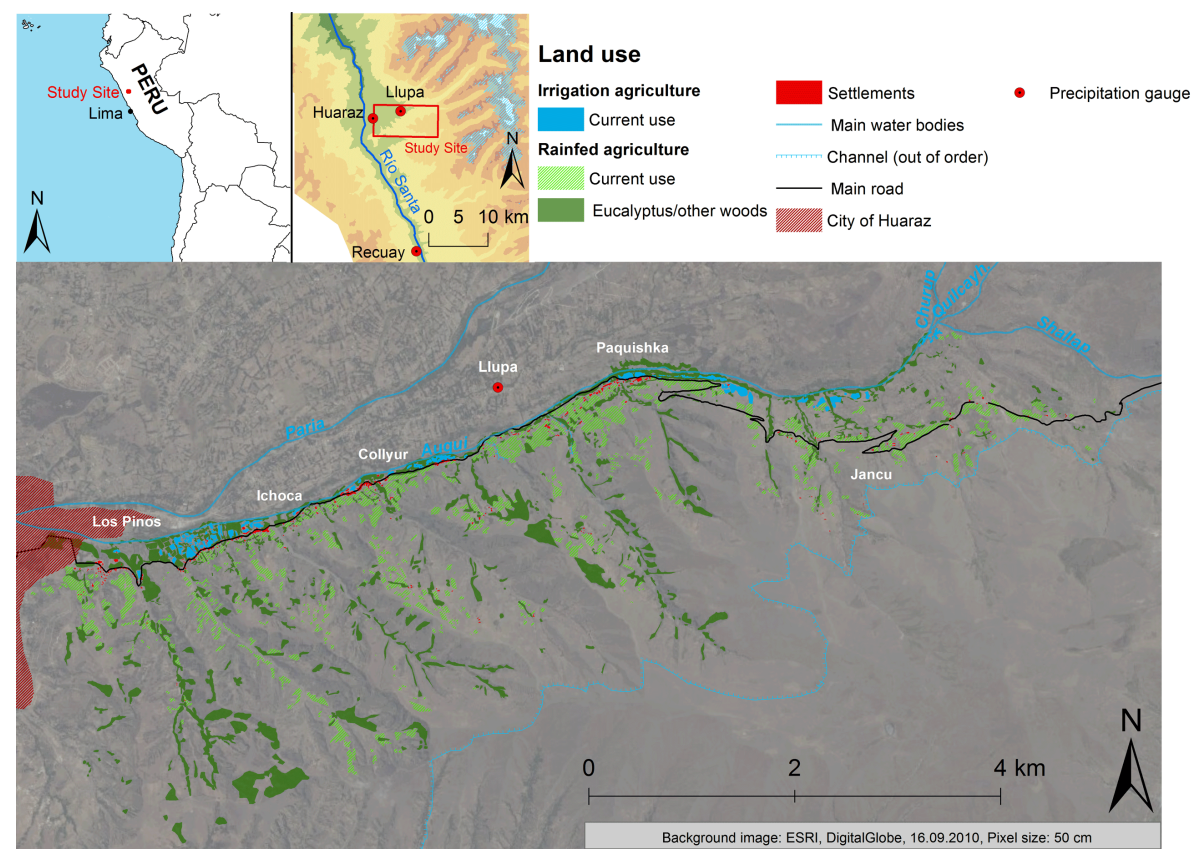

Figure 1. The study site (Cuenca Auqui) within the Rio Santa valley in Northwestern Peru.

southern side of the Río Auqui were divided into small plots and distributed among the local farmers of the Cuenca Auqui. Since then, agricultural activities are characterized by subsistence production of potatoes, grain and corn, with surpluses being sold at the markets in Huaraz. Fast-growing eucalyptus has been planted for construction, heating and cooking purposes. An irrigation channel fed by the Río Auqui could supply most farmland in the watershed, but it is out of service and the water is contaminated by heavy metals ${ }^{1}$ and thus not applicable for irrigation agriculture.

\section{Agricultural practices and peasants' accounts of changing precipitation}

\subsection{Collecting information on agricultural practices and perceived changes}

Based on the idea that local people are closely linked to their environment through continued practice of resource-based livelihoods, we collected information on the local ecological knowledge of peasants in the Cuenca Auqui as a first step. Emphasis was on local climate and environmental changes, with particular interest in agriculture and related community activities (e.g., Agrawal, 1995; Alexander et al., 2011; Klein et al., 2014). Since the memories of individuals are limited in space and time they are not able to mirror the complete natural and societal processes. We understand this type of human knowledge as a subject of continuous iteration be-

\footnotetext{
${ }^{1}$ Personal communication with Instituto de Montaña, Huaraz, July 2015.
}

tween individual and collective perceptions, practices and beliefs, modified by specific socio-political and discursive dynamics (Boillat and Berkes, 2013; Orlove and Caton, 2010; Orlove et al., 2008; Zimmerer, 2010, 2011). Accordingly, the derived information represents a snapshot of the broad and highly complex local knowledge about environment, society and history.

We conducted semi-structured and narrative interviews in all five communities of the Cuenca with peasant individuals and families of different gender and in different stages of life (Table 1). Because of traditional gender roles which define public discussions about water management and crop production as a masculine-dominated sphere a greater proportion of interviews was made with male community members. As most women are exclusively involved in reproductive work in the household and in animal husbandry, they referred to their husbands as "experts" in this field when being asked about agricultural production. The interviewees were selected by "snowball sampling" (Goodman, 2010; Heckathorn, 2011) starting with the community authority, who then indicated other families in their community. A sequence of interviews was conducted in each community until reaching saturation to ensure that no new themes emerged. We conducted the interviews in Spanish and were supported by a local translator when interviewees only spoke Quechua. All interviews included questions about household, agricultural practices (products, technology and intermediate goods, man power, agricultural calendar), community life, and questions of integrating environmental character. Main focus was on their experienced changes for each issue as well as the mutual dynamics over the last decades. Despite the frequently 
Table 1. List of interviews of farmers in the communities of Cuenca Auqui.

\begin{tabular}{lrcccc}
\hline Community & $\begin{array}{r}\text { Estimated } \\
\text { population* }\end{array}$ & $\begin{array}{c}\text { Altitude } \\
\text { range of } \\
\text { the cultivated } \\
\text { area }\end{array}$ & $\begin{array}{c}\text { Number of } \\
\text { interviews }\end{array}$ & \multicolumn{2}{c}{ Gender } \\
\cline { 5 - 7 } & 95 & $3150-3450$ & 7 & 3 & 4 \\
\hline Los Pinos & 464 & $3200-3750$ & 13 & 6 & 7 \\
Ichoca & 668 & $3250-4000$ & 4 & - & 4 \\
Collyur & 218 & $3400-4000$ & 5 & 2 & 3 \\
Paquiska & 135 & $3600-4000$ & 8 & 1 & 7 \\
Jancu & 1580 & $3150-4000$ & 37 & 12 & 25 \\
\hline Total & & & & & \\
\hline
\end{tabular}

* Source: Ministério de Salud (2013).

used vague time references like "in former times" or "before the earthquake" 2 the analysis of the interviews gave several hints for enhanced challenges in agricultural production during the "last decade". Overall, these interviews represent experiences of each individual or family which - in a communicative process - forms the collective memory of the whole community. However, information is diverse due to the fact that ecological conditions vary strongly within the Cuenca Auqui along the strong climatic gradients up-valley from west to east.

In a second step we applied additional methods of qualitative analysis. We conducted expert interviews with the community authorities, the elected political representatives of each community. They represent the community externally and internally, coordinate community activities such as maintenance of communitarian infrastructure like roads, irrigation channels, water reservoirs, and community centers, and settle disputes within the community. Additionally, we questioned officials of the Juntas Administradoras de Servicios de Saneamiento (JASS, local administrative boards of sanitation) and Juntas de Riego (committees of irrigation) that are responsible for water supply and irrigation in the communities. To capture most recent discussions on potential climate related changes we organized a participative mapping meeting in December 2013 with 16 representatives of all communities in the Cuenca. The representatives designed maps of their communities showing relevant issues and changes related to climate, agriculture, water resources and community life. A participants' comparative discussion revealed similarities as well as differences between communities in the Cuenca Auqui.

In a final step we extended our interviews to individuals and institutional experts outside the Cuenca Auqui in order to relate our knowledge to the wider upper Callejón de Huaylas. We therefore conducted "go-along interviews" (e.g., Anderson, 2004; Bergeron et al., 2014; Evans and Jones, 2011)

\footnotetext{
${ }^{2}$ In 1970 an earthquake caused huge damages in the region (Lipton, 2014).
}

with two informants from neighboring communities. One of them is a local guide from Llupa, who regularly accompanies international scientific expeditions in the Cordillera Blanca, and the other is a local historian of the community Chontayoc, located in the Cordillera Negra. These interviews yielded details about ecological conditions and agricultural practices in the Cuenca Auqui and the nearby Río Santa valley. Furthermore, we interviewed 26 representatives of public institutions and NGOs (non-governmental organizations) in Huaraz which deal with agricultural and environmental issues. From these "expert interviews" we gathered technical, agronomic and political information about structures and dynamics in agriculture, water policies, population, and migration at regional level. With these interviews we crosschecked the Cuenca Auqui peasants' reports and added details.

All interviews and meetings were recorded, transcribed and analyzed with the software MaxQDA. In the digital documents we marked all comments on agricultural practices (including experienced changes), on environmental and climate issues linked with agriculture, and on all connections established between changes in climatologic phenomenon and agriculture.

To enhance the reliability of our results, we only include individual statements which were confirmed in focus group discussions or by institutional or NGO representatives in our analysis. Since individual perceptions and collective memory in the Cuenca Auqui and beyond are mutually linked, only very few statements differ from the general view.

\subsection{Agricultural practices}

The peasant families of the Río Auqui watershed cultivate an average area of around 3 hectares per family which are distributed in small plots over different altitudes of the valley (Fig. 1) in order to guarantee diversified production for each family (Sietz et al., 2012; Vos, 2010; Zimmerer, 2011). If possible, families combine irrigation and rain-fed agriculture, but overall only few are privileged in having access to 


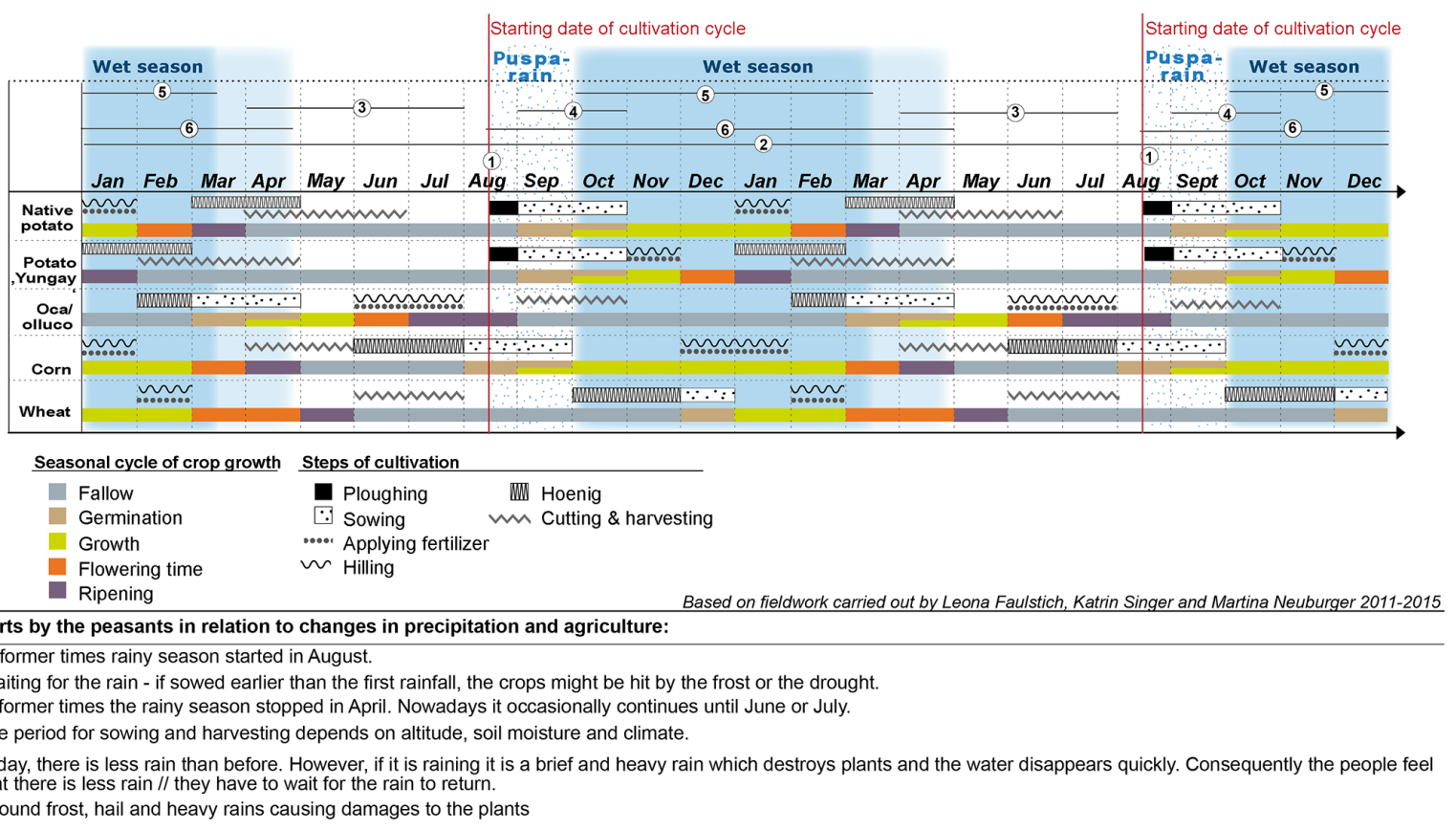

Figure 2. Agricultural calendar of the main crops used in the Cuenca Auqui.

irrigation for year-round cultivation. The large majority of the families depend entirely on rain-fed agriculture and, consequently, on precipitation. The cultivation calendar in Fig. 2 results from our interviews and fieldwork.

Rain-fed agriculture is strongly dominated by the pronounced seasonal cycle in precipitation and crops are vulnerable to changes during different phases of the cultivating cycle. Different crops and the different altitudes and climates in which they are cultivated increase the resilience of a community, yet irregularities or extremes during specific times of the agricultural year are still viewed with concern.

The first rain events after the core dry season in August and September are of particular importance as they mark the start of the rainy season. According to the reports, these first rainfall events are of gentle character, providing favorable conditions for preparing the fields. They are of great importance to agricultural life and were celebrated with festivals following ancient traditions. The enduring importance of these gentle rains is evident by the persistent use of the ancient quechua term "puspa". Potential temporal shifts of the puspa are therefore viewed with great concern by the farmers despite the sometimes broad time range suitable for agricultural practices - such as the sowing period for potatoes (Fig. 2) - due to different types of crops as well as the wide altitude range in which fields are cultivated in the Cuenca Auqui.

The main crops for subsistence in the Cuenca Auqui are potato, wheat, corn, and the traditional oca and olluco (Fig. 2). Potato (Solanum tuberosum) is typically sowed from mid-September to the end of October and harvesting starts in February and extends until June. At the altitudes above $3800 \mathrm{~m}$ a.s.l. farmers cultivate six varieties of native potatoes due to the fact that these are especially resilient to extreme climate conditions (Ministerio de Agricultura y Riego de Perú, 2013; Tapia et al., 2007). In the lower areas the commercially used ameliorated potato variety "Yungay" dominates. Compared to native varieties the vegetation period of the "Yungay" is reduced to 4 months while productivity is approximately doubled (Tapia et al., 2007). The farmers reported that the "Yungay" potato requires the use of chemical fertilizer and insecticides and is much more sensitive to dry spells in the growing period.

Besides some high altitude adapted species of wheat, corn and wheat are mainly cultivated in lower areas (below $3500 \mathrm{~m}$ a.s.l.) because they are vulnerable to frost. While corn is sowed in August or September and has a relatively long vegetation period of approximately 7 months, wheat is sowed in December and harvested between June and July. Both crops consume a lot of water and are vulnerable to dry spells in their growing period, as well as to frost and hail toward the later stages of growth. Furthermore, they are sensitive to wet conditions and heavy rain events in the ripening period.

For Oca (Oxalis tuberosa Mol.) and Olluco (Ullucus tuberosus Loz.), two traditional products of Andean agriculture adapted to high altitude climate (Tapia et al., 2007), sowing time in the Cuenca Auqui starts in March when the soils are saturated with water, and the growth period extends into the dry season. Harvesting of Oca and Olluco starts in September. Besides light rainfalls and morning dew, the 
hilling practiced is a traditional water harvesting technique that keeps the soils humid for these crops throughout the dry season. They are often planted in rotation with potato. In rare cases, they substitute potato following the same cultivation cycles. Oca and Olluco (as well as the variety mashua) are quite resistant to plagues, diseases and low temperatures (Tapia et al., 2007).

\subsection{Peasants' reports about changing precipitation and weather conditions}

Over a period referred to as the "last decade(s)", as compared to undated "past times", farmers report the following changes:

- The puspa starts only in September and sometimes comes as a single rain event only, which is insufficient for increasing the soil moisture. The farmers are confronted with a difficult problem: if they plant potato and sow corn (as the first products of the new cultivation period) before the puspa, the seeds or young plants might be damaged by water scarcity or by frost during the following dry nights. If they wait for the delayed puspa, the growing period becomes short and crop yields are reduced.

- The beginning, duration, and end of the wet and dry seasons have become more variable and, in general, rainfall has become more irregular, which complicates successful farming overall.

- The occurrences of hail and heavy rain events have become more frequent during September and October, when corn and potato are in their sensitive phase of germination and initial growth, but also throughout the entire wet season, causing high surface runoff and increased soil erosion. Damages to crops during both flowering and the harvest season are more frequent.

- Ground frost has become more frequent during September and October, damaging the crops in the early vegetation period.

The applied methods (narrative interviews and reports from group meetings) do not allow for strictly categorizing the obtained information. Thus, quantified analyses are not possible but the statements clearly converge among the communities. Our findings also mirror widely those found in an earlier study in the region (e.g., Mark et al., 2010) where the farmers perceived similar changes in the precipitation and weather patterns.

On a group to group level differences in the perceptions depend on both the location and altitude of the communities' plots as well as on the water demand characteristics of the planted crop types. Families in the higher altitude communities of Jancu and Paquishka mainly cultivate traditional crops which are relatively resistant to heavy rains and dry spells. They identify ground frosts as the biggest challenge. In turn, communities at lower elevations such as Los Pinos, Ichoca and Collyur plant mainly modern crop types on relatively steep slopes. They feel most challenged by changing precipitation variability as well as increased heavy rainfall frequency that leads to soil erosion.

Climate change is mainly seen in view of environmental justice (Schlosberg, 2007) with causes in both the industrialization in "the First World" on a global and air pollution from mining as well as air and car traffic on the regional scale. Climate change consequences are sensed as a burden without having benefits of modernization and wealth.

\section{Measured precipitation}

\subsection{Available records}

Most questions related to changes in rain-fed agriculture require at least daily temporal resolution. Only two stations in the surroundings of our study area (Fig. 1) provide daily precipitation values (07:00 to 07:00 LT) over time periods of an appropriate length. Huaraz at the bottom of our study area (3052 m a.s.l.) has a record of daily precipitation from 1996 to 2013 (with several gaps) when merging the station records of "Huaraz" and "Santiago Antunez de Mayolo". Recuay at $3445 \mathrm{~m}$ a.s.1. is about $25 \mathrm{~km}$ up-valley along the Rio Santa from Huaraz and covers a much longer period from 1964 to 2013 , with gaps of 156 days in total that could be closed with data from Recuay Sut and Laguna Ututo, 1 and $10 \mathrm{~km}$ from the Recuay station respectively. The data were made available by SENAMHI, National Meteorological and Hydrological Service of Peru.

In order to test the representativeness of these two stations for the study area we were able to use unpublished time series of weekly precipitation sums measured at Llupa (3435 m a.s.1.; from 2003-2013) relating to research projects conducted by our group in the Cordillera Blanca. Over approximately 10 years of overlapping time series, mean weekly precipitation deviated by only $2{\mathrm{~mm} w e \mathrm{w}^{-1}}^{-1}$ (Recuay-Llupa) and $0.1 \mathrm{~mm}^{-1} \mathrm{wek}^{-1}$ (Huaraz-Llupa) with correlation coefficients of 0.66 and 0.78 respectively. Thus, the magnitude and the variability of measured precipitation in Recuay and Huaraz seem to be comparable with those that can be expected in the area of the Cuenca Auqui. Lack of information about the measuring systems in Recuay and Huaraz inhibits assessing their uncertainties. Information from atmospheric model output (ERA interim with $0.75^{\circ}$ horizontal resolution) with the grid points surrounding the study area does not catch the daily variability of precipitation well enough $(r<0.6)$. In consequence, the records from $\mathrm{Re}$ cuay and Huaraz are taken for further analysis in this paper. For practical reasons values for 29 February were removed from the series. 


\subsection{Defining agri-relevant criteria for precipitation statistics}

The farmers' reports and concerns reflect the strong influence of several features in the annual precipitation cycle on farmers' lives and the agricultural year in the Cuenca Auqui. The steadiness of these characteristics determines the success or failure of sowing, growing and harvesting (Ambrosino et al., 2014; Kniveton et al., 2009; Raes et al., 2004). To extract the agriculturally relevant information from the seasonal cycles of daily precipitation to be compared with the farmers' experiences, we defined eight criteria, mainly empirically and inspired by methods presented, for example, by Laux et al. (2008). In the following, $P$ is the daily precipitation sum, $d$ is the Julian day of the respective year and $N$ is the number of days that fulfill a certain criterion.

1. Puspa: cannot be quantified in most cases due to the coarse temporal resolution and measurement accuracy of the available precipitation records.

2. Onset day wet season: $P(d)>0$ and $\operatorname{sum}(P(d: d$ $+6))>10 \mathrm{~mm}$ and $N(P(d: d+30)>0)>10$ : for the onset day of the wet season, the three requirements to be met are (i) that there is precipitation measured on that day, (ii) that the sum of measured precipitation in the next 7 days is $>10 \mathrm{~mm}$ and (iii) that the number of days with precipitation within the following 31 days ( 1 month) is $>10$. Criterion 2 was empirically defined by optically analyzing the onset days for each year with respect to the annual cycles of precipitation. Of course the transition from dry to wet season is not spontaneous, so that the selected day can just be an approximation for this transition time. In some years there would be more than one reasonable date. The additional criteria presented in the following allow detection of potential ambiguities by adding further information.

3. First sowing conditions after 1 August:

a. $\operatorname{sum}(P(d: d+2))>10 \mathrm{~mm}$ and $N(P(d: d+2)$ $>0)=3$;

b. $\operatorname{sum}(P(d: d+6))>25 \mathrm{~mm}$.

Different to the other criteria, criteria $3 a$ and $3 b$, yielding start dates for the sowing season, are based on information from literature as these criteria are more objectively assessable than, for example, the humanperceived onset of the wet season. Criterion 3a follows data presented in Table 1 in Sanabria et al. (2014) which is the only study we know that presents typical precipitation values required for planting of different crop types in the region. Three days of consecutive precipitation with total precipitation $>10 \mathrm{~mm}$ should give a rough estimate when sowing conditions for typical crops in the Cuenca Auqui (see Sect. 3.2) might be favorable for the first time after 1 August of each year (when farmers are expecting the onset of the wet season). To avoid reliance on only one criterion, we also calculated the MET criterion used in Zimbabwe (Raes et al., 2004) that advises planting if the rainfall sum exceeds $25 \mathrm{~mm}$ in 7 days (3b).

4. Dry spell during wet season: $\operatorname{sum}(P(d: d+6))$ $<10 \mathrm{~mm}$ : Criterion 4 marks dry periods ( 1 week with precipitation $<10 \mathrm{~mm}$ ). The limit of $10 \mathrm{~mm}$ of weekly precipitation to define dry spells is mostly arbitrary as there is no universal amount of weekly precipitation that is required to keep different soil types with different slopes and aspects wet for optimal plant growth, and different crops have different water demands. However, we consider this amount to be a rough indication of when soils get drier and plants might suffer from water scarcity, especially when several dry spells follow each other. We developed the criterion to meet the agricultural view of the peasants' report analyses. Thresholds are, as a consequence, different from those one would obtain when following climatological/statistical criteria such as in Marengo et al. (2001), Nieto-Ferreira and Rickenbach (2011) or Sulca et al. (2016). It is also worth mentioning explicitly that each wet spell stands for 1 week of relatively dry conditions (whereas the date used in Fig. 3 is defined as the 3rd day of the respective week) and dry spells are allowed to overlap. Each consecutive dry spell enlarges the affected period by 1 day. The overall duration of a "dry spell period" (a series of dry spells) can easily be estimated from Fig. 3 with respect to the time axis.

5. Heavy precipitation day: $P(d)>P(95 \%$ quantile): in our definition of criterion 5 , a heavy precipitation day has a precipitation total that is above the $95 \%$ quantile of all measured precipitation amounts larger than 0 . Even though the length of the time series available for Recuay and Huaraz differs between the stations, the value of the $95 \%$ quantile for daily precipitation for each is close to $17 \mathrm{~mm} \mathrm{day}^{-1}$.

6. Onset day of the dry season: $P(d)=0$ and $\operatorname{sum}(P(d: d+45))<10 \mathrm{~mm}$ : for the onset day of the dry season, the two requirements to be met are (i) that there is no precipitation measured at that day, and (ii) that the sum of measured precipitation in the next 45 days is $<10 \mathrm{~mm}$. As for criterion 2, this criterion was optimized by analyzing the calculated onset day of the dry season with respect to the annual precipitation cycles. The thresholds are again defined from an agricultural viewpoint with the dry season starting only when hardly any precipitation events occur for keeping the soil moist.

7. Wet spell during dry season: $\operatorname{sum}(P(d: d+6))$ $\geq 10 \mathrm{~mm}$ : Criterion 7 marks wetter 7 -day periods 


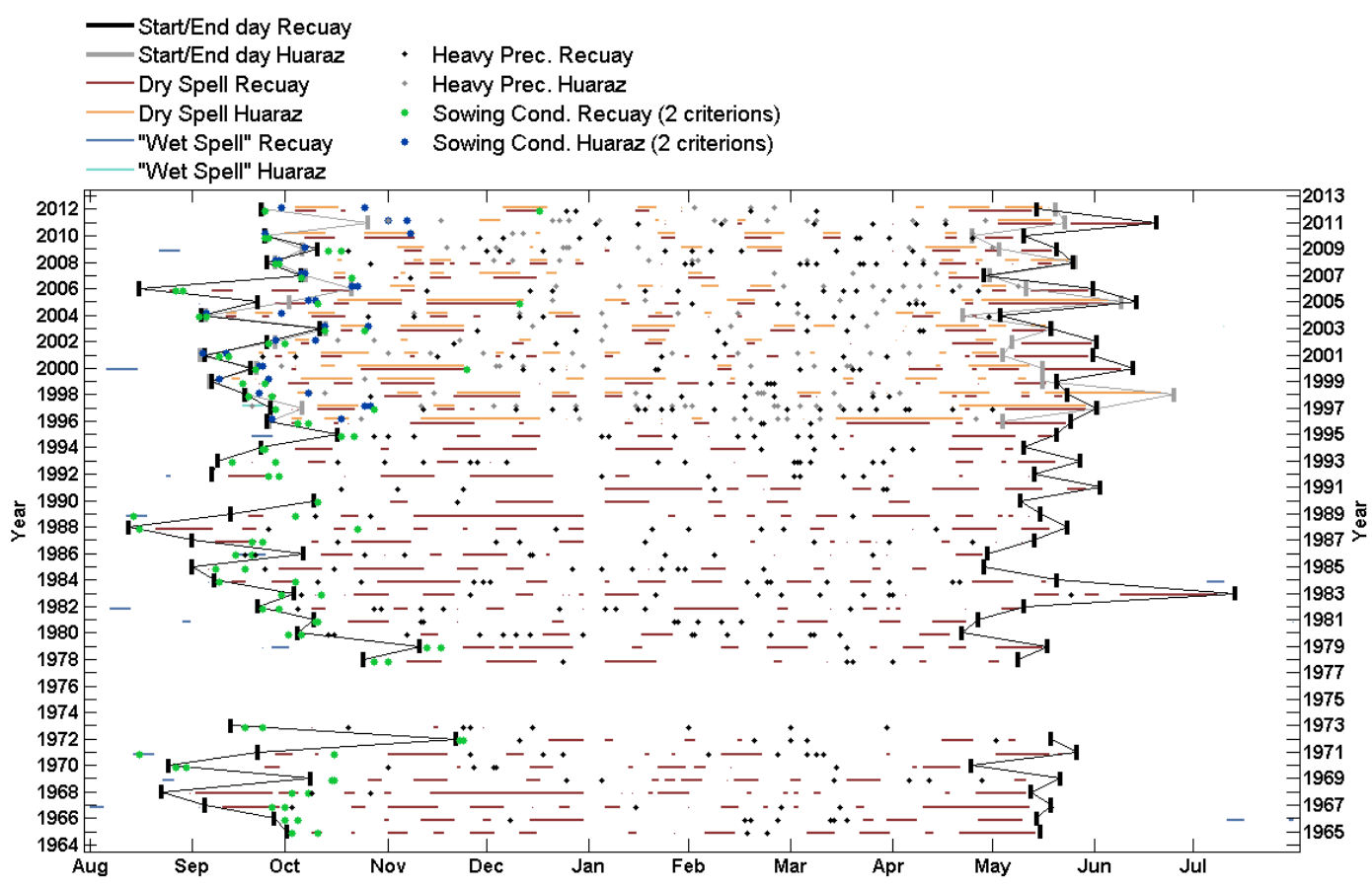

Figure 3. Precipitation features derived from daily precipitation sums based on measurements in Recuay (1964 to 2013 with gaps) and Huaraz (1996 to 2013), with the criteria described in Sect. 3.3. The $y$ axes show the calendar year in which each agricultural year (1 August to 31 July) starts.

during the defined dry season with weekly precipitation sums of at least $10 \mathrm{~mm}$. Wet spells are allowed to overlap and the overall length of "wet periods" (consecutive wet spells) can be estimated from Fig. 3 with respect to the time axis.

For a small number of years with unusual precipitation patterns, e.g., our criteria 2 and 6 did not yield reasonable results (dry season onset Recuay in 1985, wet season onset Recuay 1972) or even failed (wet season onset Recuay in 1992). We accept these minor problems as we tried to keep all eight criteria as simple as possible to facilitate comprehensibility. More sophisticated criteria could tend to over-interpret our limited information. Some other missing values in individual years (e.g., 1974-1978 in Recuay; 2012 in Huaraz) are the result of data gaps in the precipitation records.

For analyzing potential trends in the calculated features of the precipitation time series we applied the Mann-Kendall trend test (significance threshold set to the $90 \%$ confidence level) to all features presented in Figs. 3 and 4 for the 1981 to 2010 time $\operatorname{span}^{3}$ (agricultural years) available for Recuay.

\footnotetext{
${ }^{3}$ As for the year 1991 no onset date for the wet season could be calculated for Recuay, we had to ignore this year for the trend analysis of the onset dates of the wet season in the period 19812010 .
}

\subsection{Precipitation analysis}

In order to facilitate a comparison between human perceptions and memories and measured records, we classified the precipitation data along the eight criteria presented in Sect. 4.2. The results are presented in Fig. 3 by starting with the agricultural year on 1 August. In the following sections a value given for a certain year (e.g., 2003) refers to the agricultural year (1 August 2003 to 31 July 2004). Data statistics are discussed along the issues raised by the farmers and listed in Sect. 3.3.

We first comment on the puspa. As mentioned in Sect. 3.2, they are of gentle character with moistening the ground for the first time after the dry season and of high cultural importance in the community life. Yet, the distance of the rain gauges from the affected fields, the temporal resolution of the measurements, and the measuring accuracy make it impossible to detect any potential changes in the occurrence of the puspa.

As a first objective indicator of the start of agricultural year we present the onset of the wet season which should, by definition (Sect. 4.2), approximate the time when the weather conditions change from continuously dry to frequently humid. For Recuay (1965-2012), the date is typically in September or early October with the earliest onset calculated for 13 August (1988) and the latest for 20 November (1972), the arithmetic mean value being 23 September. For 1991, no onset of the wet season could be calculated 

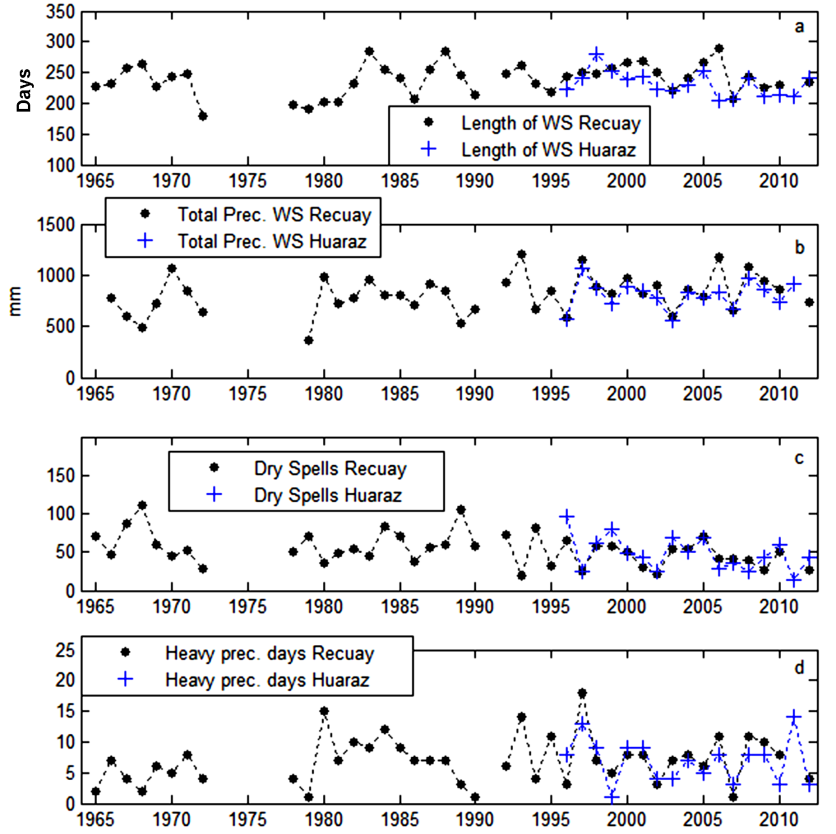

Figure 4. Time series of (a) the length of the wet season (for the agricultural years starting in the year shown on the $y$ axis), (b) the total precipitation during the wet season (for the exceptional year 1991 no wet season start could be calculated. Thus, we used the date for the first sowing conditions derived from criterion $3 \mathrm{~b}$ as the start date of the wet season for this and the following subplots), (c) the frequency of dry spells during the wet season until 23 April (earliest onsets of dry season in Huaraz and Recuay), and (d) the frequency of heavy precipitation days during the wet season.

as there was an unusual dry period from autumn 1991 to spring 1992 (also described by Schauwecker et al., 2014). For Huaraz (1996-2012) the onset day occurred typically 5 days later than in Recuay with a mean value centered on 28 September, the earliest day being 4 September (2001), the latest 25 October (2011). The mean variability of the onset was \pm 14.6 days in Recuay (44 years available) and \pm 11.1 days in Huaraz (17 years available). The results for Recuay do not show a significant trend in the onset date of the wet season. The average year-to-year variability was 22.75 days between 2003 and 2012, 13.7 days between 1993 and 2002 and 22.0 days between 1983 and 1992 for Recuay.

Analyzing the precipitation records in view of favorable sowing conditions shows that criteria $3 a$ and $3 b$ (see Sect. 4.2) are typically met between mid-September and midOctober at both measuring sites, with individual dates ranging from 30 September \pm 13.6 days $/ 10$ October \pm 12.1 days for criteria $3 \mathrm{a} / 3 \mathrm{~b}$ respectively at Huaraz, and 27 September \pm 15.4 days $/ 7$ October \pm 17.6 days for criteria $3 \mathrm{a} / 3 \mathrm{~b}$ at $\mathrm{Re}-$ cuay. As for the onset of the wet season, there is no statistically detectable trend in the Recuay record (1981-2010) regarding the occurrence of sowing conditions. Comparing the results for the two criteria shows that in most cases the dates occur only a few days apart. Only in few cases (1971, 1989, 2000, 2005 and 2012 for Recuay, 2010 for Huaraz) is criterion $3 \mathrm{~b}$ met more than a month later than criterion $3 \mathrm{a}$. As visible in Fig. 3, these latter cases were always accompanied by pronounced dry spells between the first sowing dates according to criteria $3 \mathrm{a}$ and $3 \mathrm{~b}$. Criterion $3 \mathrm{~b}$ therefore seems to be particularly conservative regarding the possible start of sowing in years with low rainfall amounts in the early wet season.

However, there are also cases where both criteria generated the same dates for good sowing conditions (e.g., 1999 and 2003) which were then followed by pronounced dry spells. Such patterns indicate particularly challenging conditions for farmers if, motivated by the first rainfalls, they sowed before the likely harmful dry spells. A rough estimate suggests that such potentially problematic conditions occurred in 7 out of 17 years between 1996 and 2012, both in Huaraz and Recuay. As a side note it is worth mentioning that on two occasions (1971 and 1989) first sowing conditions (criterion 3a) occurred during a (rare) wet spell in August (earliest date in record: 14 August 1989) which could also have provoked farmers to sow, only to face a pronounced dry period soon after.

Dry spells also occur from December to April, reflecting pronounced variability of precipitation even during the core wet season. However, dry spells during the middle of the wet season were less frequent than during the transition periods (expect for few years like 2000 at both sites and the exceptional year 1991 in Recuay). They also have lower potential to harm the plants, being in advanced stages of growth by then. Overall, as visible in Fig. 4c, we have no evidence for increased frequency of dry spells in each agricultural year (no significant trend in Recuay data). Also the mean and maximum length of the dry periods (consecutive dry spells) lack significant trends (Fig. A1).

Heavy precipitation days (here defined as $>17 \mathrm{~mm}$ day $^{-1}$ ) potentially damage crops. They were most frequent between January and March (Fig. 3). The highest numbers of days with intense precipitation occurred in Recuay in 1997 (18) and in Huaraz in 1997 (13) and 2011 (14). Days with intense precipitation were generally rare, particularly during the first years of observations in Recuay ( 5 per year on average) and have increased to 9 or 10 events per year since 1978 (Fig. 4d). In several years, heavy precipitation days occurred during the sowing seasons in September and October with the potential for particularly negative consequences by washing out the seeds or by reducing the quality of the harvest, but the average number is less than one heavy precipitation day per 2-month interval (September, October) in Huaraz and Recuay. Again, the available data records do not confirm the perceived increases (Sect. 3.3) in heavy precipitation days during that period of the agricultural year. However, the available daily precipitation sums do not allow assessments on short term convective events with locally high rainfall intensities. 
The transition from wet to dry conditions marked by the onset day of the dry season (criterion 2) towards the end of the agricultural year is centered around 17 May (earliest on 23 April in 1981; latest on 14 July, in 1984, possibly an outlier caused by our algorithm as a consequence of unusually high precipitation values of around $10 \mathrm{~mm}$ within 3 days at the beginning of July). For Huaraz the dry season onset is found to be around 16 May, earliest on 23 April in 2005 and latest on 26 June in 1999, the latter again as a consequence of unusually high precipitation during the preceding 3 days ( $>15 \mathrm{~mm}$ in total). For 1996-2012, the onset of the dry season is on average 10 days later in Recuay than in Huaraz, reflecting the slightly wetter climate there.

As with the onset of the wet season, there is quite a high year-to-year variability in the calculated onset dates of the dry season at both sites ( \pm 11.2 days for Recuay and \pm 12.8 days for Huaraz) but no significant trends towards earlier or later onsets or increases in year-to-year variability are detected. The high frequency of dry spells towards the end of the wet season only shows the typical transitional characteristics for approximately 1 month. These dry spells late in the agricultural year are considered to be a problem only if they appear unusually early, like in 1996.

The overall length of the wet season is plotted in Fig. 4a and shows a year-to-year variability between 180/204 days and 289/281 days (average 239/231 $\pm 20.5 / 16.4$ days) in Recuay (1965-2012)/Huaraz (1996-2012) respectively, but no detectable increase in year-to-year variability or significant trend toward longer/shorter wet seasons. Motivated by our agricultural viewpoint our wet seasons only end after sporadic precipitation events in May and June that have the potential to prevent the soil from totally drying out. Climatologically defined wet seasons (e.g., Marengo et al., 2001) might typically end a few weeks earlier.

Mean total precipitation during the wet season was $810 \mathrm{~mm}$ for both sites with a pronounced variability between $370 / 571$ and 1200/1064 mm for Recuay/Huaraz (Fig. 4b) respectively. The total precipitation amount during the wet season shows no significant trend in the Recuay record.

Finally, we also tested the time series of monthly precipitation (Fig. A3) with the Mann-Kendall analysis at $90 \%$ confidence level for possible trends in Recuay between 1981 and 2010. As shown in Fig. A3 (dashed red line) March precipitation increased significantly by approximately +36 mm decade $^{-1}$ but did not contribute to a significant trend in total annual precipitation (Fig. A2). Enhanced precipitation in March may detrimentally affect corn wheat and native potato plants in their flowering and ripening phase, and harvesting "Yungay" potatoes gets more difficult under wet conditions.

\section{Discussion}

Multiple environmental changes are perceived by peasants living on the eastern slopes above the city of Huaraz in the upper Callejón de Huyalas. The most prominent changes as expressed in interviews collected for this and for a former study (Mark et al., 2010) - were felt in the context of climate, such as the shrinkage of glaciers, decreasing dry season river discharge, or changes in weather patterns. These reports stimulate hypotheses to be tested against measured records. Whereas Mark et al. (2010) intensively investigated changes in (glacier-fed) river runoff, we here focused on temporal precipitation patterns in view of their impact on rainfed agriculture.

Daily time series of precipitation yield interesting insights in rainfall characteristics of the last decades and allow the comparison with peasants' statements: starting in search of the light puspa - which is considered to moisturize the soil as a minimum precondition for sowing after the dry season - we found no evidence that precipitation values got lower in the month of August or September over the last decades (Fig. A3), neither in Recuay nor in Huaraz. However, as stated before, the temporal resolution and the accuracy of the measurement systems do not allow to derive robust statements from our data whether there were changes in the puspa over time or not. Another source of uncertainty is that closer to the Andean crest precipitation events during the dry season are generally more frequent than in the main valley where the Huaraz precipitation was measured (Niedertscheider, 1990).

Nevertheless, data presented in Fig. 2 show that the agriculturally relevant sowing period for potatoes typically starts in September and continues until mid of October. For most years the calculated onset date of the wet season and the dates for the first sowing conditions after the dry season fell into that period (Fig. 3). Yet, the pronounced year-to-year variability of these dates challenges agricultural success, especially in the absence of reliable precipitation forecasts. Furthermore, it is hardly possible to predict devastating dry spells following a couple of days or weeks with good sowing conditions. Our "hind-cast" detected several such potentially harming sequences (Fig. 3) even though we could not find long term changes in the dry spell frequency (Fig. 4c).

Overall, and despite no detectable trends in the total amount of precipitation during the wet seasons (Fig. 4b) nor any other trend, the high inter-annual variability of (1) the timing of the onset of the agricultural year (as determined by the first pronounced precipitation event) and (2) dry spells during the wet season, especially during the very sensible early phase of plant growing, kept rain-fed farming constantly challenging and likely favored perceptions of water scarcity (Murtinho et al., 2013).

In the absence of adequate temporal data resolution, this study cannot give conclusive answers on the potential impacts of intense precipitation events, possibly accompanied by destructive hail and flooding. For daily rainfall sums we 
found neither a trend in the frequency of heavy precipitation days during the wet season, nor during September and October, the period recognized as most sensitive by the peasants.

We have not investigated thermal conditions but the perceived increase in the frequency of ground frosts in the early growing season (as stated by some farmers) contradicts increasing (minimum) temperatures as reported by Schauwecker et al. (2014) or in Vuille et al. (2015). The increases in minimum temperatures are reported to be most pronounced in the dry and early wet season. Also freezing level altitudes were rising during the last decades according to studies of Bradley et al. (2009) and Rabatel et al. (2013).

To extend information about climate impacts on rain-fed agriculture beyond the results presented in this study, it would be desirable to analyze local extremes in temperature and also precipitation intensities based on data collected by onsite automatic weather stations with high temporal resolution in upcoming studies.

Potential impacts of future climate conditions are currently highly uncertain due to missing or unreliable data of high spatial and temporal resolution as required for investigating impacts on rain-fed agriculture in the complex Andean terrain (Sanabria et al., 2014). Further uncertainty is due to the questionable future evolution of the El Niño Southern Oscillation (e.g., Vecchi and Wittenberg, 2010) which affects the year-to-year climate variability in the Cordillera Blanca (e.g., Garreaud et al., 2009; Vuille et al., 2008).

Beyond climate, there are several other factors not investigated within this study that could have impacts on the smallscale rain-fed farming in the study region with the potential to explain the perceived water scarcity. As peasants' reports indicate, neoliberal agrarian policies since the 1990s and the loss of manpower due to emigration, particularly of young community members (Crabtree, 2002; Lynch, 2012; Trivelli et al., 2009) are among the potential causes for the decrease in the traditional adaptive capacity of peasants in the Cuenca Auqui. Deforestation, the cultivation of water-demanding eucalyptus trees, land use change followed by soil erosion, and the change from traditional to industrial seed types are some of the manifestations of the manifold changes.

Independent from climate change, socioeconomic and ecological changes have presumably challenged rain-fed agro-production considerably. Partially because being out of the scope of our research project but also because of the lack of comprehensive information about, e.g., land use, agricultural methods, differences in income opportunities between rural and urban areas etc., we are not able to give conclusive answers in the light of the full complexity of the issue. In fact, we speculate that, because of the missing assessments on impacts of ecological and societal evolutions, climate change is currently seen as a "clear" reason for the increasing difficulties for cultivation. The perception is a blending of both individual and community sensed experiences mirroring the global discourses on climate change as regionally reproduced by NGOs, governmental institutions, and international development agencies.

The reason for the converging responses within each group (Sect. 3.3) is most likely the result of collective knowledge production on changes in weather and climate patterns, intertwined with dominant global discourses on climate change. First explorative analyses of interviews with all relevant stakeholders in the region indicate a strong linkage between local and global discourses. The positioning of small holder families within the climate change discourse may represent a strategy to be heard within the society and to benefit from climate-related political measures. Similar findings of strong interrelations between peasant perceptions, collective memory, dominant discourses and specific agricultural practices were found in other rural environments in the Andes with similar socio-ecological connections (Postigo et al., 2008; Sietz et al., 2012; Zimmerer, 1993, 2011). In order to refine and specify the multiple interactions, detailed analyses of the dynamics of climate and environmental change discourses would be needed.

\section{Summary}

We investigated agricultural practices and peasants' perceptions about climate impacts on rain-fed farming in small settlements of the Cuenca Auqui in the Cordillera Blanca, Peru, and compared these with agro-relevant precipitation features derived from daily data recorded at neighboring stations. The most important agricultural crops are potatoes (native and industrial varieties), Oca and Olluca, as well as corn and wheat. Sowing and cultivation periods vary strongly along the elevation bands of the Cuenca Auqui.

Farmers and local experts concur in their statements that changes in the climatic conditions have detrimental effects on agriculture. This also corresponds generally to findings made by Mark et al. (2010). Overall they view rain-fed agriculture as having become more challenging in recent years/decades and believe the reasons are changed precipitation patterns with less rain in August and the early wet season, more variable onset dates and durations of wet and dry seasons, and more intense rainfall events. Increased frequency of temperature-related ground frost was also reported.

Our precipitation analysis cannot confirm any precipitation changes but show high year-to-year variability in the onset dates of the wet season, the dates for the first sowing conditions after the dry season, and the number of heavy precipitation events per agricultural year. We also found that in several years pronounced dry spells occurred shortly after several wet days in the early cultivation season, encouraging the farmers to sow too early. Generally, high variability in rainfall has been shown to provoke perceptions of water scarcity in other Andean regions (Murtinho et al., 2013).

In conclusion, the year-to-year variability in seasonal and total precipitation during the agricultural year generally 
poses challenges for successful rain-fed farming in the region but no trends at all can be seen in the available precipitation data. Potential effects of heavy precipitation events and trends in their frequency could only partially be addressed in this study due to the lack of adequate data.

The study has also shown both the challenges of interdisciplinary research on complex climate change impact issues and the strong need for further developing scientific approaches that analyze all factors of concern: environmental as well as socio-political factors and their interconnectedness. The present study can only exclude precipitation changes as a likely reason for a perceived water scarcity. Precipitation information at higher spatio-temporal resolution and a series of other potential factors including factor-combinations need to be looked at for a holistic analysis of pressures on the smallscale rain-fed farming in the study region. 
Appendix A
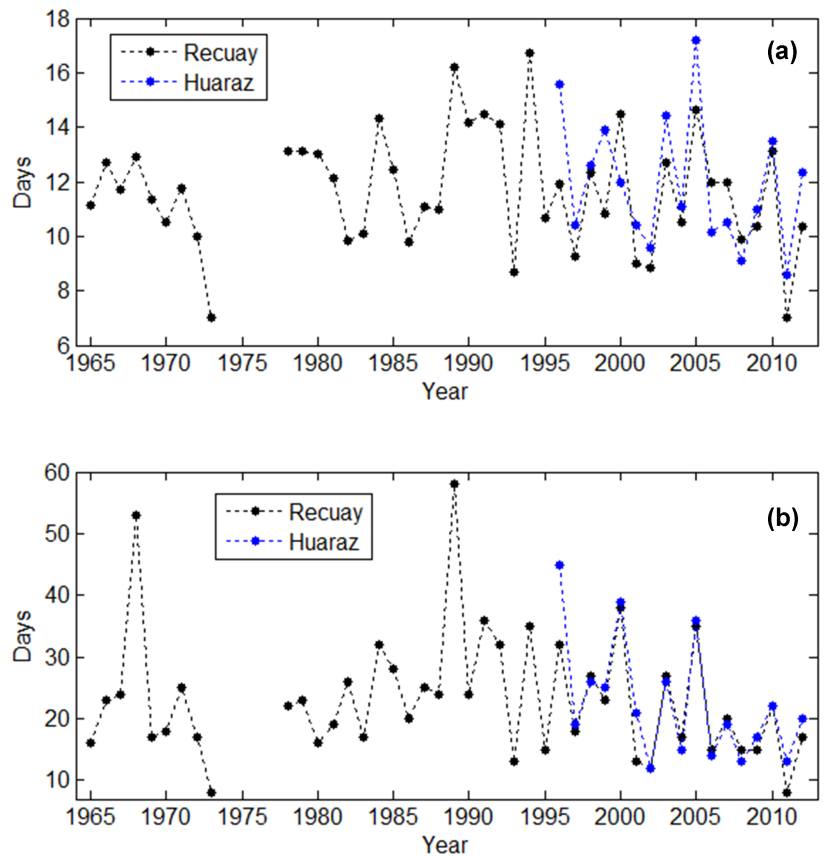

Figure A1. (a) Mean and (b) maximum length of dry periods (consecutive dry spells as defined in Sect. 4.2) for each agricultural year between 1 August and 23 April (earliest calculated onset of dry season) in Recuay and Huaraz.
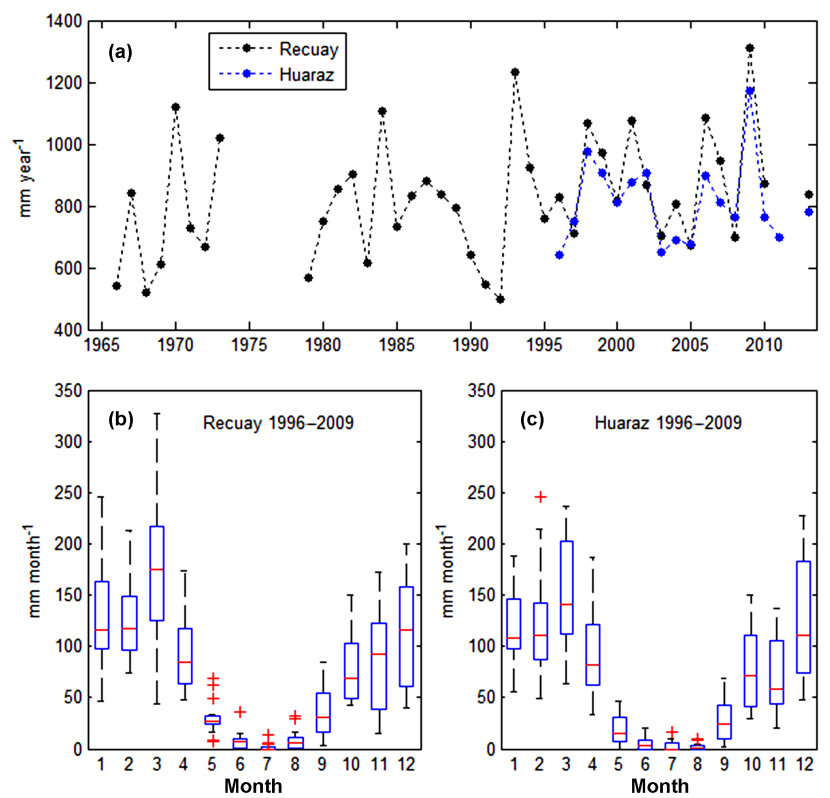

Figure A2. Annual precipitation sums in (a), boxplots for monthly precipitation sums for the overlapping period 1996-2009 for Recuay (b) and Huaraz (c) respectively. The central boxes (blue boxes) show the range of values between the 25 and $75 \%$ quantile ( $q_{25}$ and $q_{75}$ ) including the median value (50\% quantile; red horizontal line). The edges of the black vertical lines extending from the central boxes mark the highest and lowest values of the data set that are within 1.5 times $q_{75}-q_{25}$. Values are considered as outliers (red crosses) if they are larger than $q_{75}+1.5 \cdot\left(q_{75}-q_{25}\right)$ or smaller than $q_{25}-1.5 \cdot\left(q_{75}-q_{25}\right)$. 


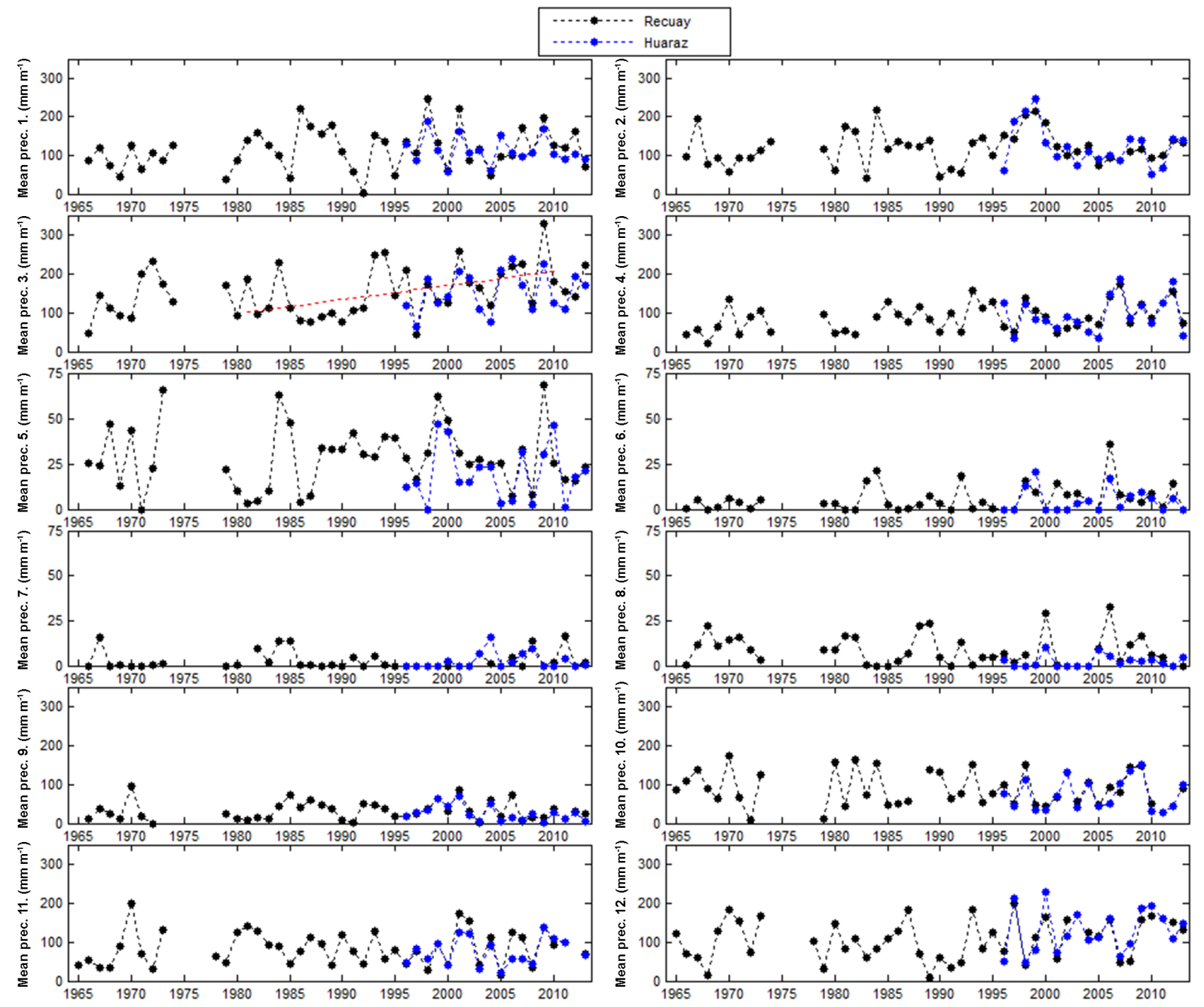

Figure A3. Monthly precipitation totals from the Recuay and Huaraz time series. The number in the $y$ label corresponds to the month. Be aware of the different $y$ axis for months 5-8 (May to August). Red dashed line shows significant trend for the period 1981-2010. 
Author contributions. W. Gurgiser performed the precipitation analysis, and coordinated and merged the contributions. I. Juen prepared the precipitation data and assisted in preparing the manuscript. K. Singer carried out the interviews and the related analysis. S. Schauwecker assisted in preparing the precipitation data. M. Hofer advised precipitation downscaling attempts. W. Gurgiser, M. Neuburger and G. Kaser wrote the paper. All authors continuously discussed the methods and results, and developed the study further.

Acknowledgements. This study was funded by an interdisciplinary DACH project of the Austrian Science Fund (FWF), project number I900-N21, and the Deutsche Forschungsgemeinschaft (DFG), project number NE 903/4-1. We thank three anonymous reviewers for their comments on an earlier version of the manuscript that led to substantial improvements of this paper. We thank Leona Faulstich, Jana Lüdemann, Nina Scheer and Alexander Döpke for their support during field work and for figure preparation. Thanks are due to SENAMHI, National Meteorological and Hydrological Service of Peru for sharing information and measurement data. We are grateful to David Parkes who checked and improved the language.

Edited by: S. B. Roy

\section{References}

Agrawal, A.: Dismantling the Divide Between Indigenous and Scientific Knowledge, Dev. Change, 26, 413-439, doi:10.1111/j.1467-7660.1995.tb00560.x, 1995.

Alexander, C., Bynum, N., Johnson, E., King, U., Mustonen, T., Neofotis, P., Oettlé, N., Rosenzweig, C., Sakakibara, C., Shadrin, V., Vicarelli, M., Waterhouse, J., and Weeks, B.: Linking Indigenous and Scientific Knowledge of Climate Change, Bioscience, 61, 477-484, doi:10.1525/bio.2011.61.6.10, 2011.

Ambrosino, C., Chandler, R., and Todd, M.: Rainfall-derived growing season characteristics for agricultural impact assessments in South Africa, Theor. Appl. Climatol., 115, 411-426, doi:10.1007/s00704-013-0896-y, 2014.

Anderson, J.: Talking whilst walking?: a geographical archaeology of knowledge, Area, 36, 254-261, 2004.

Arnall, A., Kothari, U., and Kelman, I.: Introduction to politics of climate change: Discourses of policy and practice in developing countries, Geogr. J., 180, 98-101, doi:10.1111/geoj.12054, 2014.

Baraer, M., Mark, B. G., McKenzie, J. M., Condom, T., Bury, J., Huh, K., Portocarrero, C., and Rathay, S.: Glacier recession and water resources in Peru' s Cordillera Blanca, J. Glaciol., 58, 134-150, doi:10.3189/2012JoG11J186, 2012.

Bergeron, J., Paquette, S., and Poullaouec-Gonidec, P.: Uncovering landscape values and micro-geographies of meanings with the go-along method, Landsc. Urban Plan., 122, 108-121, doi:10.1016/j.landurbplan.2013.11.009, 2014.

Boelens, R.: Cultural politics and the hydrosocial cycle: Water, power and identity in the Andean highlands, Geoforum, 57, 234247, doi:10.1016/j.geoforum.2013.02.008, 2014.

Boillat, S. and Berkes, F.: Perception and Interpretation of Climate Change among Quechua Farmers of Bolivia: Indigenous
Knowledge as a Resource for Adaptive, Ecol. Soc., 18, 21, doi:10.5751/ES-05894-180421, 2013.

Bradley, R. S., Keimig, F. T., Diaz, H. F., and Hardy, D. R.: Recent changes in freezing level heights in the Tropics with implications for the deglacierization of high mountain regions, Geophys. Res. Lett., 36, L17701, doi:10.1029/2009GL037712, 2009.

Bury, J., Mark, B. G., Carey, M., Young, K. R., McKenzie, J. M., Baraer, M., French, A., and Polk, M. H.: New Geographies of Water and Climate Change in Peru: Coupled Natural and Social Transformations in the Santa River Watershed, Ann. Assoc. Am. Geogr., 103, 363-374, doi:10.1080/00045608.2013.754665, 2013.

Bury, J. T., Mark, B. G., McKenzie, J. M., French, A., Baraer, M., Huh, K. I., Zapata Luyo, M. A., and Gómez López, R. J.: Glacier recession and human vulnerability in the Yanamarey watershed of the Cordillera Blanca, Peru, Climatic Change, 105, 179-206, doi:10.1007/s10584-010-9870-1, 2010.

Carey, M.: In the Shadow of Melting Glaciers: Climate Change and Andean Society, Oxford University Press, Oxford, 2010.

Carey, M., Baraer, M., Mark, B. G., French, A., Bury, J., Young, K. R., and McKenzie, J. M.: Toward hydro-social modeling: Merging human variables and the social sciences with climateglacier runoff models (Santa River, Peru), J. Hydrol., 518, 60-70, doi:10.1016/j.jhydrol.2013.11.006, 2014.

Chevallier, P., Pouyaud, B., Suarez, W., and Condom, T.: Climate change threats to environment in the tropical Andes: glaciers and water resources, Reg. Environ. Change, 11, 179187, doi:10.1007/s10113-010-0177-6, 2011.

Crabtree, J.: The impact of neo-liberal economics on peruvian peasant agriculture in the 1990s, J. Peasant Stud., 29, 131-161, doi:10.1080/03066150412331311049, 2002.

Dietz, K.: Der Klimawandel als Demokratiefrage: sozialökologische und politische Dimensionen von Vulnerabilität in Nicaragua und Tansania, Westfälisches Dampfboot, Münster, 2011.

Escobar, A.: Territories of Difference. Place, Movements, Life, Redes, Duke University Press, Durham, London, 2008.

Evans, J. and Jones, P.: The walking interview: Methodology, mobility and place, Appl. Geogr., 31, 849-858, doi:10.1016/j.apgeog.2010.09.005, 2011.

Garreaud, R. D., Vuille, M., Compagnucci, R., and Marengo, J.: Present-day South American climate, Palaeogeogr. Palaeocl., 281, 180-195, doi:10.1016/j.palaeo.2007.10.032, 2009.

Gelles, P.: Water and Power in Highland Peru: The Cultural Politics of Irrigation and Development, Hum. Ecol., 29, 361-362, 2001.

Goodman, L. A.: Comment: on respondent-driven sampling and snowball samping in hard-to-reach populations and snowball sampling not in hard-to-reach populations, in: Sociological Methodology, American Sociological Association, Washington DC, 347-353, 2010.

Heckathorn, D. D.: Comment: snowball versus respondent-driven sampling, Sociol. Mehtodol., 41, 355-366, doi:10.1111/j.14679531.2011.01244.x, 2011.

Juen, I., Kaser, G., and Georges, C.: Modelling observed and future runoff from a glacierized tropical catchment (Cordillera Blanca, Perú), Global Planet. Change, 59, 37-48, doi:10.1016/j.gloplacha.2006.11.038, 2007.

Kaser, G. and Osmaston, H.: Tropical Glaciers, Cambridge University Press, New York, 2002. 
Kaser, G., Juen, I., Georges, C., Gomez, J., and Tamayo, W.: The impact of glaciers on the runoff and the reconstruction of mass balance history from hydrological data in the tropical Cordillera Blanca, Perú, J. Hydrol., 282, 130-144, doi:10.1016/S00221694(03)00259-2, 2003.

Kaser, G., Großhauser, M., and Marzeion, B.: Contribution potential of glaciers to water availability in different climate regimes, P. Natl. Acad. Sci. USA, 107, 20223-20227, doi:10.1073/pnas.1008162107, 2010.

Klein, J. A., Hopping, K. A., Yeh, E. T., Nyima, Y., Boone, R. B., and Galvin, K. A.: Unexpected climate impacts on the Tibetan Plateau: Local and scientific knowledge in findings of delayed summer, Global Environ. Change, 28, 141-152, doi:10.1016/j.gloenvcha.2014.03.007, 2014.

Kniveton, D. R., Layberry, R., Williams, C. J. R., Peck, M., Parks, S., and Oxford, R.: Trends in the start of the wet season over Africa, Int. J. Climatol., 29, 1216-1225, doi:10.1002/joc.1792, 2009.

Laux, P., Kunstmann, H., and Bardossy, A.: Predicting the regional onset of the rainy season in West Africa, Int. J. Climatol., 342, 329-342, doi:10.1002/joc.1542, 2008.

Lennox, E. and Gowdy, J.: Ecosystem governance in a highland village in Peru: Facing the challenges of globalization and climate change, Ecosyst. Serv., 10, 155-163, doi:10.1016/j.ecoser.2014.08.007, 2014.

Lipton, J. K.: Lasting Legacies: Conservation and Communities at Huascaran National Park, Peru, Soc. Nat. Resour., 27, 820-833, doi:10.1080/08941920.2014.905888, 2014.

Lynch, B. D.: Vulnerabilities, competition and rights in a context of climate change toward equitable water governance in Peru's Rio Santa Valley, Global Environ. Change, 22, 364-373, doi:10.1016/j.gloenvcha.2012.02.002, 2012.

Marengo, J. A., Liebmann, B., Kousky, V. E., Filizola, N. P., and Wainer, I. C.: Onset and End of the Rainy Season in the Brasilian Amazon Basin, J. Climate, 14, 833-852, doi:10.1175/15200442(2001)014<0833:OAEOTR>2.0.CO;2, 2001.

Mark, B. G. and Seltzer, G. O.: Tropical glacier meltwater contribution to stream discharge: a case study in the Cordillera Blanca, Peru, J. Glaciol., 49, 271-281, doi:10.3189/172756503781830746, 2003.

Mark, B. G. and Seltzer, G. O.: Glacier Recession in the Peruvian Andes: Climatic Forcing, Hydrologic Impact and Comparative Rates Over Time, in: Global Change and Mountain Regions: An Overview of Current Knowledge, edited by: Huber, U. M., Bugmann, H. K. M., and Reasoner, M. A., Springer, Dordrecht, 205214, 2005.

Mark, B. G., Bury, J., McKenzie, J. M., French, A., and Baraer, M.: Climate Change and Tropical Andean Glacier Recession: Evaluating Hydrologic Changes and Livelihood Vulnerability in the Cordillera Blanca, Peru, Ann. Assoc. Am. Geogr., 100, 794-805, doi:10.1080/00045608.2010.497369, 2010.

Ministerio de Agricultura y Riego de Perú: Cultivos de importancia nacional, Lima, 2013.

Ministério de Salud: Informe del Estado situacional de los sistemas de auga de consumo humano desl ambito rural - Distrito de Huaraz, Lima, 2-3, 2013.

Murtinho, F., Tague, C., Bievre, B., Eakin, H., and Lopez-Carr, D.: Water Scarcity in the Andes: A Comparison of Local Perceptions and Observed Climate, Land Use and Socioeconomic
Changes, Hum. Ecol., 41, 667-681, doi:10.1007/s10745-0139590-z, 2013.

Neuburger, M.: Global discourses and the local impacts in Amazonia. Inclusion and exclusion processes in the Rio Negro region, Erdkunde, 62, 339-356, doi:10.3112/erdkunde.2008.04.06, 2008.

Niedertscheider, J.: Untersuchungen zur Hydrographie der Cordillera Blanca (Peru), Master Thesis, Leopold Franzens University, Innsbruck, Innsbruck, 1990.

Nieto-Ferreira, R. and Rickenbach, T. M.: Regionality of monsoon onset in South America: A three-stage conceptual model, Int. J. Climatol., 31, 1309-1321, doi:10.1002/joc.2161, 2011.

Orlove, B. and Caton, S. C.: Water Sustainability: Anthropological Approaches and Prospects, Annu. Rev. Anthropol., 39, 401-415, doi:10.1146/annurev.anthro.012809.105045, 2010.

Orlove, B., Wiegandt, E., and Luckman, B. H. (Eds.): The place of glaciers in natural and cultural landscapes, in: Darkening Peaks: Glacier Retreat, Science, and Society, University of California Press, Berkeley, Calif., 3-19, 2008.

Postigo, J. C., Young, K. R., and Crews, K. A.: Change and Continuity in a Pastoralist Community in the High Peruvian Andes, Hum. Ecol., 36, 535-551, doi:10.1007/s10745-008-9186-1, 2008.

Rabatel, A., Francou, B., Soruco, A., Gomez, J., Cáceres, B., Ceballos, J. L., Basantes, R., Vuille, M., Sicart, J.-E., Huggel, C., Scheel, M., Lejeune, Y., Arnaud, Y., Collet, M., Condom, T., Consoli, G., Favier, V., Jomelli, V., Galarraga, R., Ginot, P., Maisincho, L., Mendoza, J., Ménégoz, M., Ramirez, E., Ribstein, P., Suarez, W., Villacis, M., and Wagnon, P.: Current state of glaciers in the tropical Andes: a multi-century perspective on glacier evolution and climate change, The Cryosphere, 7, 81102, doi:10.5194/tc-7-81-2013, 2013.

Raes, D., Sithole, A., Makarau, A., and Milford, J.: Evaluation of first planting dates recommended by criteria currently used in Zimbabwe, Agr. Forest Meteorol., 125, 177-185, doi:10.1016/j.agrformet.2004.05.001, 2004.

Sanabria, J., Calanca, P., Alarcón, C., and Canchari, G.: Potential impacts of early twenty-first century changes in temperature and precipitation on rainfed annual crops in the Central Andes of Peru, Reg. Environ. Change, 14, 1533-1548, doi:10.1007/s10113-014-0595-y, 2014.

Schauwecker, S., Rohrer, M., Acuña, D., Cochachin, A., Dávila, L., Frey, H., Giráldez, C., Gómez, J., Huggel, C., Jacques-Coper, M., Loarte, E., Salzmann, N., and Vuille, M.: Climate trends and glacier retreat in the Cordillera Blanca, Peru, revisited, Global Planet. Change, 119, 85-97, doi:10.1016/j.gloplacha.2014.05.005, 2014.

Schlosberg, D.: Defining environmental justice, Oxford University Press, Oxford, 2007.

Sietz, D.: Regionalisation of global insights into dryland vulnerability: Better reflecting smallholders' vulnerability in Northeast Brazil, Global Environ. Change, 25, 173-185, doi:10.1016/j.gloenvcha.2014.01.010, 2014.

Sietz, D., Choque, S. E. M., and Lüdeke, M. K. B.: Typical patterns of smallholder vulnerability to weather extremes with regard to food security in the Peruvian Altiplano, Reg. Environ. Change, 12, 489-505, doi:10.1007/s10113-011-0246-5, 2012.

Sulca, J., Vuille, M., Silva, Y., and Takahashi, K.: Teleconnections between the Peruvian central Andes and Northeast Brazil during 
extreme rainfall events in Austral Summer, J. Hydrometeorol., 17, 499-515, doi:10.1175/JHM-D-15-0034.1, 2016.

Tapia, M. E., Fries, A. M., Mazar, I., and Rosell, C.: Agronomía de los cultivos andinos, in Guia de campo de los cultivos andinos (Field Guide to Andean Crops), FAO, Rom, ANPE, Lima, 21-122, available at: http://www.fao.org/docrep/ 010/ai185s/ai185s04.pdf (last access: 25 May 2016), 2007.

Trivelli, C., Escobal, J., and Revesz, B.: Desarrollo rural en al sierra. Aportes para el debate, Lima, (IPCA, GRADE, IEP, CIES, Peru, 2009.

Vecchi, G. A. and Wittenberg, A. T.: El Niño and our future climate: where do we stand?, Wiley Interdiscip. Rev. Clim. Chang., 1, 260-270, doi:10.1002/wcc.33, 2010.

Vos, J.: Riego campesino en los Andes. Seguridad hídrica y seguridad alimentaria en Ecuador, Perú y Bolivia, IEP, Concertacion, Lima, 2010.

Vuille, M., Francou, B., Wagnon, P., Juen, I., Kaser, G., Mark, B., and Bradley, R.: Climate change and tropical Andean glaciers: Past, present and future, Earth-Sci. Rev., 89, 79-96, doi:10.1016/j.earscirev.2008.04.002, 2008.
Vuille, M., Franquist, E., Garreaud, R., Lavado Casimiro, W. S., and Cáceres, B.: Impact of the global warming hiatus on Andean temperature, J. Geophys. Res.-Atmos., 120, 3745-3757, doi:10.1002/2015JD023126, 2015.

Zimmerer, K. S.: Soil erosion and labor shortages in the Andes with special reference to Bolivia, 1953-91: Implications for "Conservation-With-Development", World Dev., 21, 1659-1675, doi:10.1016/0305-750X(93)90100-N, 1993.

Zimmerer, K. S.: Retrospective on Nature - Society Geography: Tracing Trajectories (1911-2010) and Reflecting on Translations, Ann. Assoc. Am. Geogr., 100, 1076-1094, doi:10.1080/00045608.2010.523343, 2010.

Zimmerer, K. S.: The landscape technology of spate irrigation amid development changes: Assembling the links to resources, livelihoods, and agrobiodiversity-food in the Bolivian Andes, Global Environ. Change, 21, 917-934, doi:10.1016/j.gloenvcha.2011.04.002, 2011. 